\title{
Agressie in de tram
}

\section{Het perspectief van trambestuurders}

\author{
Thaddeus Müller \& Roy Zeestraten
}

\section{Inleiding}

In dit artikel presenteren wij de bevindingen van een verkennend onderzoek naar hoe een categorie werknemers met een publieke taak, trambestuurders, reageert op agressieve reizigers. Het onderzoek waarop dit artikel is gebaseerd, heeft plaatsgevonden in Den Haag en bestond uit observaties en interviews. De maatschappelijke relevantie van het thema geweld tegen personeel met een publieke functie kan moeilijk onderschat worden. Er is veel ophef over in de media en het wordt gezien als een teken van algehele verloedering (Van Stokkom, 2010). Een meer sociologische benadering ziet geweld tegen personeel met een publieke taak als een uiting van veranderende gezagsverhoudingen, waarin de autoriteit van personeel met een publieke functie niet per definitie wordt geaccepteerd. In dit verband kan verwezen worden naar een proces van informalisering, democratisering en individualisering, waardoor burgers mondiger zijn geworden en er sprake is van een gezagscrisis en wantrouwen jegens de overheid en haar personeel. De overheid heeft diverse maatregelen genomen om de agressie tegen te gaan. Straffen zijn verhoogd, camera's zijn in trams geïnstalleerd en de inzet van controleteams is opgevoerd (Van der Aa, Pemberton, Vorm, Kesteren \& Letschert, 2008). De wetenschappelijke relevantie van dit onderzoek ligt in het gegeven dat wij meer inzicht proberen te krijgen in de manier(en) waarop personeel met een publieke functie reageert op agressieve reizigers. In de wetenschappelijke literatuur over dit onderwerp wordt doorgaans weinig aandacht besteed aan de reactie van de publieke dienstverleners in het interactieproces dat voorafgaat aan agressie. In dit artikel kijken wij naar de ontwikkeling van (agressieve) interacties en beschrijven die vanuit het perspectief van de geïnterviewde trambestuurders. Wij kijken in ons artikel naar hoe zij betekenissen geven aan agressie in de tram. Kort samengevat proberen wij in dit artikel een antwoord te geven op de volgende vragen:

1 Wat is het verloop van interacties tussen trambestuurders en hun klanten waarin sprake is van agressie (vanuit het perspectief van trambestuurders)?

2 Welke strategieën hanteren trambestuurders tijdens het verloop van deze interacties?

3 Hoe geven trambestuurders betekenissen aan deze interacties en hoe beïnvloedt dit het verloop hiervan?

In de literatuur over dit onderwerp wordt vaak afwisselend verwezen naar agressie, geweld en intimidatie. In de interviews werden deze begrippen vaak door elkaar gebruikt door de respondenten. Er is strikt genomen een onderscheid tus- 
sen agressie en geweld. Agressie is meer omvattend. Het verwijst niet alleen naar gedrag, maar ook naar een houding. Geweld heeft daarentegen vooral betrekking op gedrag, waarbij vaak een onderscheid gemaakt wordt tussen verbaal geweld en fysiek geweld. Uit de gesprekken komt naar voren dat het laatste minder voorkomt, zoals blijkt in dit artikel en wordt bevestigd door onderzoek naar aard en omvang van geweld tegen publiek personeel (Abraham, Flight \& Roorda, 2011: 24-25). ${ }^{1}$ Intimidatie heeft te maken met de dreiging van fysiek geweld, maar in het perspectief van de respondenten kan een blik ook als intimiderend worden ervaren. In het perspectief van de respondenten gaat het bij agressie in de tram om een scala van gedragingen die beginnen bij relatief onschuldig luidruchtig gedrag van jongeren, via woordenwisselingen en het gebruik van krachttermen naar fysieke confrontaties.

In de komende pagina's bespreken we eerst de literatuur over agressie gericht tegen personeel met een publieke taak, waarna we ingaan op de gehanteerde methode. Vervolgens gaan we in op de bevindingen van het onderzoek dat uiteenvalt in drie gedeeltes: het voorkomen van agressie, het reageren op agressie en de variatie daarin onder de trambestuurders. In de slotbeschouwing beantwoorden we de onderzoeksvragen, komen terug op de besproken literatuur en geven we enkele onderzoeksaanbevelingen.

\section{Literatuur over agressie tegen personeel met een publieke taak}

De literatuur over agressie gericht tegen trambestuurders is uiterst beknopt. Daarom kijken wij naar publicaties die betrekking hebben op een bredere categorie: personeel met een publieke taak, zoals conducteurs, controleurs, brandweerlieden en ambulancepersoneel. In de afgelopen jaren zijn diverse studies verschenen over agressie tegen dit personeel. De meeste studies hebben een beschrijvend karakter, waarin nauwelijks oog is het voor het verloop van de interacties. ${ }^{2}$ Tevens is er weinig aandacht voor de rol van personeel met een publieke functie bij het verloop van deze interacties en hoe het perspectief van dit personeel op agressieve reizigers het verloop van de interacties bepaalt. Ook zien we dat er weinig wordt ingezoomd op een specifieke beroepsgroep, waardoor de relatie tussen de werkcontext en het verloop van agressieve interacties niet voldoende wordt onderkend.

Over agressie tegen politieagenten zijn wel diverse studies verschenen, die (ten dele) oog hebben voor het interactieproces (Vynckier, De Haan, Adang \& Goossens, 2012; Alpert, Dunham \& MacDonald, 2004; Timmer, 2005). Deze studies

1 Uit hun studie komt naar voren dat 57\% van de ondervraagden geconfronteerd is met verbale agressie in de afgelopen twaalf maanden, waarvan $15 \%$ elf of meer keren en $20 \%$ met fysieke agressie, waarvan 2\% elf of meer keren (Abraham, Flight \& Roorda, 2011: 24-25).

2 Er is een reeks van beschrijvende studies die met name gericht zijn op de aard en omvang van geweld tegen personeel met een publieke functie (Montfort et al., 2009; Jacobs, Jans \& Roman, 2009; Sikkema, Abraham \& Flight, 2007; Vught \& Bogaerts, 2007), de factoren die hierop van invloed zijn (Raven \& Driessen, 2004; Vught \& Bogaerts, 2007) en de kenmerken van de daders (Bakker, Drost \& Roeleveld, 2010). 
zijn in principe waardevol en geven inzicht in het dynamische interactieproces dat leidt tot geweld, maar het gaat hier om een specifieke categorie personeel met een publieke taak, omdat zij gebruik kunnen maken van machtsmiddelen, zoals arrestatie en het hanteren van wapens, waar andere categorieën personen dat niet kunnen doen. Dit onderscheid wordt ook erkend door andere onderzoekers.

'De eerste categorie betreft groepen wier taak het (mede) is toezicht te houden op de naleving van regels en zonodig naleving af te dwingen. Het ligt voor de hand dat zij veel geconfronteerd worden met geweld van burgers die niet van plan zijn de regels na te leven. Omdat het hun functie is naleving af te dwingen zijn zij meestal ook op een of andere wijze toegerust om geweld te beheersen. Voor de politie geldt dat zij bevoegdheden heeft (artikel 8 Politiewet) en verder door training ook goed is voorbereid op geweld (vergeleken met de andere beroepsgroepen) (Middelhoven \& Driessen, 2001: 7).'

Omdat de werkcontext van politieagenten aanzienlijk afwijkt van die van ander personeel met een publieke taak, is een op zich interessante vergelijking niet eenvoudig te maken en gaat die de invalshoek van dit artikel te boven. Daarom laten we de studies over politieagenten hier buiten beschouwing.

We gaan nader in op vier studies waarin wel oog is voor de rol van personeel met een publieke functie bij het ontstaan van onveilige situaties (Bergman, Valk \& De Vries, 2013; Blokland \& Soenen, 2004; Roeleveld \& Bakker, 2010; Verschuren, Fischer \& Zwirs, 2011). We kunnen deze studies onderscheiden in twee categorieën: (1) studies die een scala van beroepen met een publieke taak onder de loep nemen en (2) studies die inzoomen op een beroepscategorie. De eerste categorie heeft betrekking op de studies van Roeleveld en Bakker (2010) en van Bergman, Valk en De Vries (2013). Aan de hand van interviews wordt in beide studies ingegaan op hoe het personeel met een publieke taak reageert op agressieve personen. Uit deze Nederlandse studies komt duidelijk naar voren dat personeel met een publieke functie in bepaalde mate invloed uitoefent op situaties die uit de hand lopen. Zo wordt in de studie van Roeleveld en Bakker (2010) aangegeven dat dit personeel diverse strategieën hanteert, zoals het stellen van grenzen, een de-escalerende houding aannemen, het inschatten van de situatie en van de eigen emotionele gemoedstoestand (ibid.: 33-35). In de studie van Bergman, Valk en De Vries (2013), waarin tevens gebruik is gemaakt van documentenanalyse en interviews met slachtoffers, wordt ook aangegeven dat het optreden van personen met een publieke taak soms bijdraagt aan het escaleren van situaties.

De interviews uit deze studies blijken een goede methode om zicht te krijgen op het emic-perspectief van personeel met een publieke taak. Maar omdat die interviews betrekking hebben op diverse beroepsgroepen, is de relatie met de specifieke werkcontext moeilijk te achterhalen, waardoor het inzicht in de betekenisgeving van agressie en de toepassing van bepaalde strategieën belemmerd wordt. Aandacht voor personeel met eenzelfde publieke functie in een vergelijkbare werkcontext, zoals in ons geval de trambestuurders in Den Haag, kan dit euvel verhelpen. 
De studies van Blokland en Soenen (2004) en van Verschuren, Fischer en Zwirs (2011) gaan wel in op een specifieke beroepsgroep: respectievelijk trambestuurders en treinconducteurs. Het artikel van Blokland en Soenen (2004), over veiligheid in de tram, heeft betrekking op Antwerpen en is gebaseerd op observaties. In dit artikel wordt de rol van trambestuurders als passief omschreven: 'Trambestuurders trokken zich helemaal terug uit de relationele sfeer op de tram. Zij bestuurden alleen de tram. Wel waren ze vaak in gesprek met collega's of bekenden. Zo construeerden zij hun eigen parochiale sfeer' (2004: 181). Door deze opstelling oefenen zij geen invloed uit op hoe personen zich (horen) te gedragen in de tram. Oftewel, zij laten het definiëren van gedrag als gewenst of ongewenst over aan de sociale dynamiek in de tram. Door hun vermijdende houding zijn ze debet aan een onveilige situatie in de tram, zo stellen de auteurs. Hoewel het artikel van Blokland en Soenen een rijk etnografisch beeld geeft van de sociale wereld van de tram en de rol van trambestuurders daarin, krijgt de lezer weinig zicht op het perspectief van de trambestuurders. Wellicht omdat deze studie grotendeels gebaseerd is op observaties.

Verschuren, Fischer en Zwirs (2011) koppelen slachtofferschap van Nederlandse treinconducteurs aan de wijze waarop zij sociale informatie verwerken. Zij richten zich dus wel op hoe deze beroepsgroep betekenis geeft aan agressieve interacties. Uit het onderzoek, dat uitgevoerd is aan de hand van vignetten en een enquête, komt het volgende naar voren: 'Treinconducteurs die minder boosheid en/of angst ervaren, zullen de bedreigende/negatieve cues (...) wellicht minder benadrukken en daardoor minder vaak slachtoffer worden' (ibid.: 208). Een andere relevante bevinding is dat er sprake is van een groep conducteurs die de onderzoekers categoriseren als 'agressieve slachtoffers'. Deze personen zien de intenties van de ander als vijandig, reageren hier fel op door bijvoorbeeld te provoceren en kunnen hun gevoelens van angst en woede minder beheersen (Verschuren, Fischer \& Zwirs, 2011: 196). Het blijkt dat de personen die vaker reactieve agressie vertonen ook vaker slachtoffer zijn. In het artikel van Verschuren, Fischer en Zwirs (2011) wordt de sociale realiteit waarin de treinconducteurs handelen, teruggebracht tot een drietal vignetten die weinig recht doen aan de ontwikkeling van de interacties die leidt tot verbaal en/of fysiek geweld. Hoe de treinconducteurs reageren, wordt vervolgens weergegeven in een oorzaak-en-gevolgmodel, waarin hun handelen gestuurd lijkt te worden door emoties als woede en angst. Door deze opzet geeft deze studie weinig zicht op hoe personeel met een publieke taak handelt in een dynamisch interactieproces.

Wij letten in onze benadering wel op de ontwikkeling van de interactie(s) tussen trambestuurders en reizigers. Hierbij kijken wij hoe een interactie verloopt in de tijdspanne van een zich ontwikkelend conflict, waarbij we nagaan welke activiteiten de betrokken actoren ontplooien. Deze benadering ontlenen we aan het werk van Athens (2005). Zoals we zullen zien in dit artikel gaat het bij de ontwikkeling van agressieve interacties vaak om een patroon van actie en reactie waarin de betrokkenen kunnen besluiten om zich terug te trekken, of om hun wil aan de ander op te leggen. In de terminologie van Athens gaat het om een opeenvolging van interacties, waarin een van de betrokkenen de superieure positie claimt door te bepalen hoe de ander zich dient te gedragen - waarna deze persoon zijn of 
haar ondergeschikte positie kan accepteren of afwijzen. Athens geeft aan dat er verschillende stadia zijn die voorafgaan aan een fysieke confrontatie, zoals een verbale confrontatie zonder enige intentie om fysiek geweld aan te wenden, die over kan gaan in een verbale intimidatie, die explosief is, maar waarin geen fysiek geweld wordt gehanteerd.

Wie de relevante literatuur over geweld tegen personeel met een publieke taak beschouwt, ziet dat een dergelijke interactiebenadering weinig wordt gehanteerd. Door niet nauwkeurig in te gaan op de dynamiek van een interactie ontstaat geen gedetailleerd inzicht in het proces dat leidt tot gewelddadige interacties.

Een ander onderbelicht aspect in de eerder besproken studies over geweld tegen werknemers met een publieke functie is hoe hun betekenisgeving van agressie beïnvloed wordt door hun visie op 'eigenwaarde' en 'mannelijkheid'. Dit is opmerkelijk, omdat in diverse studies naar geweld, zoals over jongeren en criminaliteit (Messerschmidt, 2000, 2004), relschoppers (Leiden, Arts \& Ferwerda, 2009) en uitgaansgeweld (Anderson, Daly \& Rapp, 2009), wel nadrukkelijk wordt verwezen naar 'mannelijkheid'. Messerschmidt is bij uitstek de expert die hierover heeft gepubliceerd. Hij gebruikt het begrip 'hegemonic masculinity' voor een traditionele vorm van mannelijkheid, die betrekking heeft op onder andere autonomie, eergevoel, risico's nemen, territoriumdrift en lichamelijke weerbaarheid. Messerschmidt (1993, 2000, 2004) geeft aan dat mannelijkheid een divers karakter heeft en niet een vaststaand gegeven is, maar telkens opnieuw in de dagelijkse praktijk bevestigd dient te worden. Vandaar dat hij het heeft over 'doing gender' (zie ook West \& Zimmerman, 1987). Het is vooral in situaties waarin mannelijkheid in het geding is en betwist wordt - Messerschmidt spreekt over 'gender degradation' (Messerschmidt, 2004: 49) - dat mannen teruggrijpen op agressief gedrag waarmee ze hun mannelijkheid (eer) herstellen en bevestigen. In dit artikel verkennen we de (eventuele) rol die mannelijkheid speelt bij de ontwikkeling van agressie in de tram.

\section{Methode}

Onze studie, die heeft plaatsgevonden in het voorjaar van 2011, heeft een exploratief karakter, omdat nog weinig bekend is over hoe trambestuurders optreden als handelende en betekenisgevende personen tijdens het verloop van agressieve interacties. Het verkennende onderzoek heeft bestaan uit observaties en interviews. We besteden in het vervolg van het artikel vooral aandacht aan de bevindingen die uit de interviews naar voren zijn gekomen, omdat we hier met name ingaan op het perspectief van de trambestuurders.

De interviews zijn gehanteerd om zicht te krijgen op het verloop van agressieve interacties en hoe trambestuurders daarin optreden als betekenisgevende en handelende personen. Op deze manier kunnen ze in hun eigen woorden aangeven waarom en hoe ze reageren op agressie in de tram. De tweede auteur is via een kennis in contact gekomen met trambestuurders in Den Haag. Hij heeft circa vijftig uur doorgebracht in de tramremise en is op deze wijze in contact gekomen met de respondenten. De interviews zijn afgenomen in deze remise. In totaal zijn 
negentien interviews afgenomen, zeventien met trambestuurders en twee met hun leidinggevenden. Alle interviews zijn opgenomen, zodat ze later uitgewerkt en beluisterd konden worden. De interviews werden gevoerd aan de hand van een topiclijst en hadden een semigestructureerd karakter; de respondenten hadden de vrijheid om nader in te gaan op onderwerpen die tijdens het interview naar voren kwamen en relevant waren voor het onderzoek. Op deze wijze krijgen we via hun ogen zicht op situaties die uit de hand (dreigen te) lopen. De gemiddelde duur van de interviews was circa een uur. De respondenten waren op een persoon na allen mannen, tussen de 28 en 58 jaar oud en werkten tussen anderhalf en ruim dertig jaar bij het openbaar vervoersbedrijf (gemiddeld vijftien jaar).

Elk interview is geanalyseerd, zodat per interview een overzicht ontstond van de meest voorkomende thema's. In de praktijk is de analyse als volgt gegaan. De informatie is per interviewtopic beknopt in Excel verwerkt. Op deze manier konden alle interviews met elkaar vergeleken worden per topic. Op deze wijze ontstonden verschillende datamatrixen, waarmee een overzicht werd verkregen en gezocht kon worden naar overeenkomsten en verschillen. Met behulp van de methode van de constante vergelijking (Strauss \& Corbin, 1998), die betrekking had op de gegevens binnen elk interview en op de interviews onderling, hebben we onze eerste tentatieve inzichten en bevindingen steeds meer verfijnd en aangescherpt. In de praktijk betekende dit dat de aandacht afwisselend uitging naar het hogere abstractieniveau van de analyse, zoals de gevonden patronen in de datamatrixen, en de data uit de interviews. Op deze iteratieve wijze hebben we inzicht gekregen in het verloop van agressieve interacties, hoe trambestuurders betekenis geven aan deze interacties en hoe dit hun handelen bepaalt.

\section{Bevindingen}

Naast het besturen van de tram bestaat de functie van trambestuurders globaal uit twee andere taken, (1) dienstverlening en (2) het handhaven van de openbare orde in de tram. Met betrekking tot het laatste krijgen ze een training over het omgaan met ongewenst gedrag. Uit het onderzoek komen diverse strategieën naar voren die trambestuurders gebruiken om de openbare orde in de tram te handhaven. Het begrip strategieën gebruiken we hier voor handelingen om een situatie te beïnvloeden. Het woord heeft dus een algemenere betekenis dan wat doorgaans onder strategieën wordt verstaan: uitgedachte en geplande handelingen om een specifiek doel te bereiken. Eerst gaan we in op strategieën die een algemeen karakter hebben en die trambestuurders hanteren ter voorkoming van agressie in tram. Vervolgens bespreken we strategieën die trambestuurders toepassen als er toch sprake is van agressie in de tram. De verschillende strategieën sluiten elkaar overigens niet uit en de respondenten gebruiken die aanvullend op elkaar. ${ }^{3}$ Tot slot gaan we in op de twee perspectieven, zakelijk versus persoonlijk,

3 In het onderzoek zijn we ook ingegaan op het beleid rond agressie in de tram, de training hieromtrent en de afwikkeling van incidenten, zoals ondersteuning door derden, het melden van incidenten en het verwerken hiervan, maar gezien de beschikbare ruimte voor dit artikel kunnen we daar in dit verband geen aandacht aan besteden. 
die van invloed zijn op hoe trambestuurders reageren op agressie in de tram. Ook gaan we nader in op de rol van masculiene normen en waarden bij deze perspectieven.

Hoewel agressie weinig voorkomt in de tram, houden trambestuurders hier wel rekening mee en proberen ze interacties die kunnen leiden tot agressie en geweld te voorkomen. Ook worden ze tijdens agressieve interacties voor de keuze gesteld of zij wel of niet interveniëren. In dit artikel zal blijken dat dit cruciaal is voor het wel of niet escaleren van een situatie.

\section{Het voorkomen van agressie in de tram}

Uit de interviews komt naar voren dat trambestuurders veel aandacht besteden aan het voorkomen van potentiële conflictsituaties. Twee strategieën hebben hier betrekking op. Ten eerste geven trambestuurders aan dat het belangrijk is dat zij hun eigen emoties goed kunnen beheersen. De bestuurders maken duidelijk dat het belangrijk is om ontspannen en rustig te zijn tijdens het omgaan met klanten. Deze strategie richt zich op twee bronnen van mogelijke stress: werk en privé. Uit de interviews blijkt dat de noodzaak om op tijd te rijden een belangrijke rol speelt bij het ontstaan van werkstress. Bestuurders proberen het belang van de dienstregeling te relativeren, maar dat lukt niet altijd. Zij geven ook aan dat het belangrijk is om privéproblemen niet mee naar het werk te nemen. Als dit niet lukt, kunnen de trambestuurders prikkelbaar zijn, waardoor conflicten ontstaan. Een respondent gaf bijvoorbeeld aan dat hij geïrriteerd reageerde op vervelend gedrag van schooljeugd nadat hij slecht nieuws had ontvangen over een vriend van hem.

Trambestuurders zijn zich dus ervan bewust dat hun eigen voorkomen van invloed is op hoe klanten hen benaderen en handelen op basis hiervan. Zo geeft een trambestuurder aan dat hij zich opstelt als een gastheer: 'En als ze dan wat willen vragen en hulp willen dan ga ik ze ook extra goed helpen.' Met de wijze waarop de trambestuurders zich presenteren, proberen zij invloed uit te oefenen op het gedrag van de reizigers. Een ander voorbeeld van deze strategie is het gebruik van humor:

'Ja, humor werkt bij mij wel. Het is vaak als je komt aangereden en ze kijken geïrriteerd op hun klokje dan maak ik een opmerking en dan is het van "oké, relaxt".' (respondent 2, man, 40 jaar)

De tweede strategie die wordt gehanteerd om een problematische situatie te voorkomen is het categoriseren van klanten en waakzaam zijn. Hierbij kijken bestuurders enerzijds naar groepskenmerken en anderzijds naar individuele kenmerken. In het eerste geval besteden zij aandacht aan algemene kenmerken, zoals groepsomvang, leeftijd en etniciteit, in het laatste geval letten ze nauwkeurig op het voorkomen van klanten. Beide manieren van categoriseren liggen in elkaars verlengde. Op basis van het uiterlijk van klanten delen zij hen in in categorieën van reizigers waarvan ze verwachten dat die wel of geen problemen zullen veroorzaken. Bestuurders stellen dat zij hiervoor in de loop der jaren een zesde zintuig hebben ontwikkeld. Hiermee verwijzen ze naar hun ervaringskennis, waardoor ze 
op basis van diverse aspecten van hoe reizigers zich voordoen op een bijna intuïtieve wijze bepalen of iemand problemen kan gaan veroorzaken.

'Ja, ik maak wel eens een inschatting van mensen. (...) Ik zit nu twaalf jaar op de tram en je gaat op een gegeven moment zien wat mensen van plan zijn. (...) Dat zie je ook bij mensen die in de tram stappen, aan hun blik, aan hun houding, aan hun doen en laten.' (respondent 3 , man, 38 jaar)

Als het gaat om het letten op groepskenmerken, verwijzen bestuurders naar diverse risicocategorieën, zoals (mannelijke) verslaafden, scholieren en allochtone jongeren. Uit ervaring weten ze dat deze groepen vaak ongewenst gedrag vertonen. Hun houding ten opzichte van deze categorieën wordt tevens beïnvloed door de omvang van de groep. Bij drie of meer personen zijn bestuurders alert.

'We hebben heel veel problemen, overlast door de schooljeugd. Maar dat is inherent aan die groep. Als je die groep vervoert en ze zijn met zijn allen samen ... Al vervoer je er twee dan is er niets aan de hand, maar al vervoer je er tien dan is iedereen druk en schreeuwen.' (respondent 16, man, 38 jaar)

Trambestuurders geven tevens aan dat ze alert zijn op bepaalde locaties en tijdstippen. Door hun werkervaring beschikken ze over een 'mentale plattegrond' (Spradley, 1972) van locaties waar ze ongewenst gedrag kunnen verwachten, zoals in de nabijheid van scholen en de plekken waar methadon wordt verstrekt. Tevens zijn ze zich ervan bewust dat het gedrag van de gebruikers van het openbaar vervoer wisselt per dagdeel en seizoen. 's Avonds laat is het onrustiger dan overdag. De respondenten geven aan dat zij ook waakzaam zijn als er evenementen zijn in de stad.

'Tijd van het jaar speelt mee, bijvoorbeeld met drukte van de kermis. (...) En dan denk je als dat maar niet uit de hand gaat lopen, want ze zijn elkaar zo aan het uitdagen. Ik zit dan wel best wel vrij gespannen op de bok [de bestuurdersstoel]. Je houdt alles tien keer beter in de gaten als normaal.' (respondent 13, man, 34 jaar)

\section{Omgaan met agressie in tram}

De hiervoor beschreven strategieën die betrekking hebben op het voorkomen van agressieve interacties worden ook gehanteerd tijdens deze interacties, zoals zal blijken uit deze paragraaf. Hier zullen we vooral ingaan op de volgende drie strategieën die trambestuurders hanteren tijdens agressieve interacties (verbaal en/of fysiek): (1) negeren, (2) interveniëren op afstand en (3) interveniëren van nabij. Uit het onderzoek blijkt dat reizigers zelden zelf ingrijpen of de trambestuurders ondersteunen. Als gevolg hiervan spelen ze ook geen rol in de hierna beschreven voorbeelden.

Negeren (1) is volgens trambestuurders een van de belangrijkste en meest efficiënte manieren om te reageren op regelovertredend gedrag. Ze geven aan dat ze niet overal op ingaan, omdat anders situaties snel uit de hand zullen lopen. Dit 
heeft vooral betrekking op verbaal geweld en ongewenst gedrag van jongeren. Uit ervaring weten ze dat dit gedrag vaak van korte duur is, waardoor het in hun ogen niet loont om te reageren. Ook geven ze aan dat het zo regelmatig voorkomt, dat het niet efficiënt is om hier steeds op in te gaan. Ze vertellen dat als ze dat wel doen, de dienstregeling in gevaar kan komen.

De trambestuurders maken duidelijk dat zij op hun werkplek meer accepteren dan in hun privéleven. Dit hangt nauw samen met hun professionele identiteit. Veel agressief gedrag zou in het privéleven ervaren worden als een persoonlijke schoffering, maar door het gedrag te plaatsen in de context van hun werk - 'de knop omdraaien' - accepteren ze het (zie ook Jacobs, Jans \& Roman, 2009).?

'Spugen is helemaal uit den boze bij mij, dat is wel meerdere keren gebeurd. Maar ik veeg het af en laat het gaan. Dat moet je wel, anders lig je elke dag te rollebollen.' (respondent 12, man, 56 jaar)

In het geval van aanhoudend regelovertredend gedrag, doorgaans achter in de tram, kunnen trambestuurders op diverse manieren interveniëren. Ze maken hierbij een voor hen betekenisvol onderscheid dat betrekking heeft op fysieke nabijheid. De tweede categorie strategieën wordt getypeerd door lichamelijke afstand ten opzichte van de overlastgevers (2), de derde door lichamelijke nabijheid (3): trambestuurders stappen op overlastgevers af en spreken hen van nabij aan op hun gedrag. Trambestuurders hebben het in dit verband over 'naar achter gaan'.

Het ingrijpen waarbij de fysieke afstand wordt gehandhaafd (2) kan vier vormen aannemen: (a) via de spiegel aankijken, (b) aanspreken via de intercom, (c) de tram niet laten vertrekken en (d) hulp inroepen van derden, zoals de politie. Zo kunnen trambestuurders reizigers op een non-verbale manier aanspreken op hun gedrag door hen via de spiegel aan te kijken (a).

'Als er problemen zijn met jongeren dan zitten ze voor $100 \%$ achterin. Dan zitten ze te roken of zo. Maar ze kijken altijd in de spiegel. Oogcontact is belangrijk. Dan roken ze en als ik dan oogcontact maak dan zie ik ze reageren van "ja is goed, ik maak hem uit".' (respondent 10, man, 51 jaar)

Trambestuurders stellen dat de manier waarop zij kijken niet confronterend of denigrerend dient te zijn. Dit is belangrijk omdat anders passagiers het gevoel kunnen krijgen dat ze niet gerespecteerd worden en gezichtsverlies lijden. Een andere manier om reizigers achter in de tram te laten blijken dat gedrag niet acceptabel is, is het gebruikmaken van de intercom (b). Het is van groot belang dat het toespreken op zo'n manier plaatsvindt, dat de ander geen gezichtsverlies lijdt. Anders kunnen reizigers het gevoel krijgen dat ze in een hoek worden gedrukt, waardoor de situatie kan escaleren (zie ook Kaldenbach, 2008). Een gehanteerd script bij het aanspreken op ongewenst gedrag is het rustig en objectief benoemen van de consequenties van het gedrag en aangeven dat de daders daar verantwoordelijk voor zijn. 
'Dan vraag ik aan die jongens van doe het alsjeblieft niet, de mensen willen op tijd daar zijn. Ik wil op tijd zijn want de dienstregeling komt in gevaar. Doe het alsjeblieft niet, klaar. Vaak hoor ik niets en dan worden ze gecorrigeerd door elkaar. Van “joh Pietje doe het niet”. Dat zie ik gewoon.' (respondent 2, man, 40 jaar)

Een derde middel om de publieke orde te herstellen tijdens het continueren van de fysieke afstand is het stoppen van de rit (c). Zo laten sommige bestuurders de tram net zo lang stil staan totdat de problemen zijn opgelost, of totdat de daders zijn uitgestapt. Ook hierbij spreekt de trambestuurder op een ontspannen manier de jongeren aan en legt hen uit wat de consequenties zijn van hun gedrag.

'Als ze de deuren open houden dan zeg ik altijd "jullie willen of naar school of naar je werk, of je trein halen, daar staat een bepaalde tijd voor. Ik ben al op mijn werk, al sta ik hier drie uur. Ik ben er al, mij zit je niet in de weg". Op een gegeven moment zie je dan dat het ophoudt of dat het zich naar buiten verplaatst.' (respondent 14, man, 43 jaar)

Als de eerder besproken strategieën niet het gewenste effect sorteren, kunnen trambestuurders via de centrale verkeersleiding vragen om bijstand van controleurs of politie (d).

De derde strategie is het opheffen van de fysieke afstand door op de reizigers af te stappen en hen aan te spreken op hun gedrag. Sommige bestuurders geven aan dat ze zelden om bijstand vragen en bij voorkeur zelf 'naar achter gaan'. Ze lossen liever zelf de problemen op. De keuze tussen deze twee strategieën is bepalend voor het verloop van het interactieproces tussen bestuurders en reizigers. Een deel van de bestuurders maakt duidelijk dat zij nooit 'naar achter' gaan, omdat zij vinden dat de kans op escalatie hierdoor vergroot wordt.

'Dat geef ik mijn leerlingen ook mee. We zijn al fout als we van onze stoel afstappen. Daar staat eigenlijk al de doodstraf op. Dan geef je het bedrijf de handvaten om te zeggen van: je hebt het zelf uitgelokt. Al komen ze naar jou toe dan staat het ook op camerabeelden. (...) En al ga je naar achter, in je eentje tegen een man of zes ... Voorin zijn de communicatiemiddelen en kan je altijd een noodoproep plaatsen. Achterin kan dat niet.' (respondent 14, man, 43 jaar)

Ook bij het naar achter gaan speelt het maken van een rustige indruk een belangrijke rol.

'Ik zag hem komen aanrennen en heb de deur ontgrendeld. Het eerste wat hij doet is boem tegen de deur trappen. Toen heb ik netjes de tram stilgezet, ben ik naar achter gelopen. Het was volle bak. Ik ga naar hem toe en zeg "meneer, wilt u uitstappen". Hij zegt: "Ah, rijd die tram man". Ik zeg nee. Bij mij is het zo en eigenlijk hoort een mens ook zo te zijn. Hoe hoger de toon van de tegenpartij, hoe rustiger ik optreed. Ga je in dezelfde toon mee, dan is het 
eind zoek en dan kunnen hele erge dingen gebeuren. Dus hij weer schreeuwen, ik zeg "nee, je gaat rustig uitstappen". Dat doe je thuis toch ook niet, deuren intrappen. (...) Uiteindelijk heeft hij zijn excuus aangeboden en ben ik weer gaan rijden.' (respondent 10, man, 51 jaar)

De geïnterviewde trambestuurders geven aan dat ze bij het naar achter gaan gebruikmaken van een de-escalerende houding (zie ook Roeleveld \& Bakker, 2010). In deze situatie zien we dat trambestuurders dus zo veel mogelijk proberen te vermijden om mee te gaan in een woordenwisseling, omdat ze weten dat die kan transformeren in een fysieke confrontatie. Door een kalme houding aan te nemen en rustig op de ander in te praten, proberen ze ervoor te zorgen dat de situatie normaliseert.

'Als je klappen krijgt dan heb je het ook zelf gedaan. Ik probeer de problemen al voor te zijn. Je moet ze voor zijn. Je moet het niet tot het hoogtepunt laten komen. (...) Met praten kan een hoop en ook je houding speelt daarin mee.' (respondent 12, man, 56 jaar)

Soms grijpen bestuurders fysiek in. In uitzonderlijke gevallen heeft dit te maken met het verliezen van zelfbeheersing door woede of angst, waardoor ze niet in staat zijn strategisch te handelen en de controle over de situatie verliezen. In andere gevallen komt het alleen tot een fysieke reactie nadat een aantal stappen zijn doorlopen die eindigen met een aanvallende beweging van een reiziger. Eerst is er sprake van overlast of agressief gedrag, zoals het maken van te veel geluid en het lastigvallen van andere passagiers. De trambestuurder kan ervoor kiezen om niets te doen of om te interveniëren. Het resultaat van de interventie kan tweeledig zijn: de reizigers stoppen met hun regelovertredend gedrag of gaan hiermee door. De trambestuurder heeft weer een keuze tussen negeren of interveniëren. Doorgaans heeft de tweede interventie een meer dwingend karakter. De overlastgever kan besluiten om te stoppen, de interventie te negeren en door te gaan, of om te kiezen voor verbale/fysieke intimidatie.

Een voorbeeld van een verbale intimidatie die uitloopt op een fysieke confrontatie heeft betrekking op een groep jonge mannen die andere reizigers lastigvallen en flessen bier door de tram gooien. Als eerste stap heeft de trambestuurder de jongeren gewaarschuwd via de intercom. Dat sorteerde geen effect. De jongeren begonnen hierna ook de bestuurder uit te schelden. Op dat moment heeft de bestuurder de wagen stilgezet en is naar achter gegaan. Hij heeft de jongeren verteld dat ze de tram moesten verlaten. Twee van de vier jongeren gaven hier gehoor aan en gingen naar buiten. De andere twee bleven in de tram. Hij had het idee dat deze twee jongeren uit waren op een vechtpartij. Het gebeurde allemaal in 'fracties van secondes'.

'Ik ben echt wel tekeer gegaan. Ik moest me wel verdedigen. Er zijn rake klappen gevallen, meer aan hun kant dan aan mijn kant. Ik had niets.' (respondent 8 , man, 40 jaar) 
Het derde en laatste voorbeeld van een fysieke confrontatie is er een waarbij er een vechtpartij ontstaat tussen reizigers onderling. De trambestuurder stapte hier op af om de ruzie te sussen. Op dat moment werd er door een van de vechtende reizigers een mes getrokken. Hij richtte het mes tegen de trambestuurder.

'Ik kan met mijn achtergrond [vechtsport] met zo een situatie uit de voeten. Ik heb die man zijn been gebroken en ik heb hem op de halte eruit gedonderd en ben doorgereden. Hij is uiteindelijk niet in de buurt gekomen om te steken.' (respondent 17, man, 46 jaar)

\section{Twee perspectieven op agressie in de tram}

Uit de interviews komt een tweeledig beeld naar voren: trambestuurders die wel 'naar achter gaan' en zij die dat zelden of nooit doen. Bestuurders uit de eerste categorie proberen zo veel mogelijk zelf op te lossen. Hun perspectief op de tram heeft een persoonlijk karakter, waarin zij zich laten leiden door individuele voorkeuren. Zij vragen zelden om bijstand. Deze respondenten hebben een fors postuur en bovendien zijn twee van hen gespecialiseerd in zelfverdediging. Deze bestuurders hebben de tram 'geprivatiseerd' en beschouwen het als hun 'winkeltje'. Ze zien de tram als hun territoir en als een verlengde van henzelf.

'Ik ga meer dan gemiddeld naar achter. Dat is denk 3 tot 4 keer per week (...) In principe is het mijn winkeltje en daar moet je je gedragen. Als je daar anders over denkt dan moet je maar een andere tram gebruiken.' (respondent 17, man, 43 jaar)

Deze bestuurders mengen zich vaak in situaties waar hulp inroepen van derden wellicht een betere optie zou zijn geweest en volgens de richtlijnen van het openbaar vervoersbedrijf ook zou hebben moeten plaatsvinden. Deze mannen kiezen in een agressieve interactie nadrukkelijk voor een dominante positie en spelen de rol van bovenliggende partij (zie Athens, 2005). Negeren en om bijstand vragen is voor hen een aantasting van hun mannelijke trots. Een belangrijk gevolg hiervan is dat zij meer in aanraking komen met verbaal en fysiek geweld dan andere bestuurders.

De bestuurders die kiezen voor een dominante positie ontlenen een gevoel van eigenwaarde en trots aan het gegeven dat zij zelf situaties die uit de hand (dreigen te) lopen kunnen beheersen. In hun doen en laten is er op verschillende manieren sprake van doing gender (Messerschmidt, 1993). Zij benadrukken in hun gedrag diverse aspecten van mannelijkheid, zoals autonomie, risico's nemen, territoriumdrift en lichamelijke weerbaarheid.

'Meestal slaan ze mijn tram over. Degene die ik echt daadwerkelijk te pakken heb gehad (...). Dan kijken ze eerst en dan pakken ze de volgende tram. Dan heb ik toch op een of andere manier respect afgedwongen. Dat ze toch denken van ooh wacht even, daar moeten we niet mee sollen en dat ze dan mijn tram overslaan.' (respondent 8 , man, 40 jaar) 
Voor bestuurders die wel op hun plek blijven zitten, speelt trots of respect in relatie tot incidenten in de tram nauwelijks een rol. Hun perspectief op de werkcontext heeft eerder een zakelijk karakter en valt te typeren met het begrip emotionele distantie. Ze zien het regelovertredend gedrag niet als een aantasting van hun eigenwaarde, maar als een situatie die kan leiden tot vertraging van de rit en tot escalatie. Zij maken zichzelf bij voorkeur ondergeschikt aan het op tijd rijden van de tram. Deze bestuurders gaan zelden naar achter om zelf een probleem op te lossen. Zij wachten eerder af of vragen om bijstand. Deze bestuurders vinden dat bij het naar achter gaan het risico te groot is dat een situatie uit de hand loopt. Zo legde een respondent uit waarom hij nooit van zijn 'plek afkomt' om een probleem in de tram op te lossen.

'Nooit, nooit zelf, nee. Ik hoor wel eens verhalen van andere collega's. Het loopt altijd slecht af. Als je van je plek afkomt, dat is niet goed.' (respondent 11, man, 33 jaar)

\section{Slotbeschouwing}

In dit artikel zijn we nagegaan hoe trambestuurders reageren op agressie in de tram. Uit ons artikel blijkt dat de reactie van trambestuurders verband houdt met hoe zij betekenis geven aan agressie van reizigers en aan de werkcontext. Door nadrukkelijk in te gaan op het verloop van agressieve interacties hebben we ook geconstateerd dat trambestuurders in verschillende fases strategieën hanteren om de situatie te normaliseren. Hoe het personeel zich opstelt, is van grote invloed op het verloop van de interactie. Voordat er überhaupt sprake is van agressie, houden trambestuurders hiermee rekening door zelf kalm en rustig te blijven, klantvriendelijk over te komen en door de reizigers goed in de gaten te houden. In het geval van terloopse verbale agressie en overlast van jongeren achter in de tram is negeren een veelvoorkomende strategie. Anders kan de situatie escaleren en de dienstregeling in gevaar komen. Als het ongewenste gedrag achter in de tram aanhoudt, kunnen de bestuurders er voor kiezen de reizigers hierop aan te spreken. Ook hierbij is het van belang dat zij hun emoties beheersen en zich strategisch opstellen: de interacties met reizigers, in het bijzonder jonge mannen, moeten een niet-confronterend karakter hebben, omdat zij anders gezichtsverlies kunnen lijden en de situatie kan escaleren. Een deel van de trambestuurders kiest ervoor om naar achter te gaan en de reizigers van nabij aan te spreken op hun gedrag. Ook hierbij zijn beheersing van de eigen emoties en strategisch indruk maken van groot belang. Trambestuurders die naar achter gaan, proberen rustig te blijven en niet mee te gaan in de confrontatie.

Uit het onderzoek komt naar voren dat er twee perspectieven te onderscheiden zijn, een zakelijk perspectief waarin trambestuurders zich opstellen als werknemers en een persoonlijk perspectief, waarin zij zich laten leiden door individuele voorkeuren, waarin masculiene normen en waarden een belangrijke rol spelen. Degenen die naar achter gaan, delen het tweede perspectief. In het laatste geval interveniëren bestuurders in situaties waar zij volgens het protocol van het ver- 
voersbedrijf hulp hadden moeten inroepen van derden. Deze bestuurders zien agressie in de tram als een aantasting van hun mannelijkheid en willen die herstellen door zelf te interveniëren. Het gevolg is wel dat zij hierdoor meer in aanraking komen met verbaal en fysiek geweld dan de andere bestuurders. De bestuurders die niet naar achter gaan en de hulp van derden inroepen vinden zelf interveniëren in dergelijke situaties een te groot risico. Agressie in de tram heeft voor hen een andere betekenis. Ze zien die niet als een aantasting van hun eigenwaarde, maar als een situatie die kan leiden tot vertraging van de rit en escalatie. Op het eerste gezicht lijkt het gedrag van het personeel dat naar achter gaat verband te houden met het begrip 'reactieve agressie' uit de studie van Verschuren, Fischer en Zwirs (2011). Degenen die erop afstappen en de reizigers aanspreken op hun gedrag komen namelijk vaker in contact met geweld. Maar bij een nadere beschouwing constateren wij dat het personeel doorgaans de confrontatie niet blind van woede en angst aangaat, maar dat zij juist door rustig over te komen en hun emoties te beheersen personen proberen te kalmeren. Voordat de situatie escaleert, proberen zij de orde te herstellen en de situatie onder controle te krijgen. Het begrip 'reactieve agressie' verhult de complexiteit en het dynamische verloop van de interacties die leiden tot verbaal en fysiek geweld. Het begrip 'reactieve agressie' doet bovendien weinig recht aan de afwegingen van trambestuurders en verbeeldt hen als personen die de greep op de situaties verliezen vanwege gebrekkige zelfbeheersing. Misschien gaan onze bevindingen ook op voor treinconducteurs en ander personeel met een publieke functie. Nader onderzoek moet dit uitwijzen.

Wij ronden ons artikel af met een aantal onderzoeksaanbevelingen, waarin we de nadruk leggen op de complexiteit en de dynamiek van de totstandkoming van agressie tegen personeel met een publieke taak. Hoewel onze bevindingen gebaseerd zijn op een casus in een specifieke ruimtelijke context (Den Haag) en wij hierdoor logischerwijze geen algemene uitspraken kunnen doen die betrekking hebben op andere categorieën personeel met een publieke taak, veronderstellen wij dat de bevindingen uit ons onderzoek gebruikt kunnen worden bij het verkrijgen van dieper inzicht in de totstandkoming van agressie tegen personeel met een publieke taak.

Ten eerste komt uit ons onderzoek duidelijk naar voren dat het van belang is om nadrukkelijk aandacht te besteden aan een beroepsgroep en de werkcontext waarin deze groep functioneert. De werkcontext is bepalend voor het type agressie waarmee de werknemers worden geconfronteerd en de strategieën die zij kunnen hanteren om situaties te normaliseren. Zo blijkt bijvoorbeeld dat het wel of niet toepassen van interventies nadrukkelijk samenhangt met de noodzaak van het op tijd laten rijden van de tram. Negeren als strategie blijkt bijvoorbeeld vaak het meest efficiënt te zijn om de dienstregeling niet in gevaar te laten komen. Maar het verloop van agressieve interacties wordt ook bepaald, zoals al eerder is aangegeven, door hoe trambestuurders betekenis geven aan hun werkcontext. Het is daarom af te raden om onderzoek te doen naar een breed scala van beroepsgroepen, waarbij telkens slechts een beperkt aantal interviews per beroepsgroep wordt uitgevoerd (Roeleveld \& Bakker, 2010; Bergman, Valk \& De 
Vries, 2013). Dit gaat ten koste van de rijke beschrijving die noodzakelijk is om inzicht in deze materie te krijgen.

Ten tweede willen we benadrukken dat het van groot belang is om het verloop van de agressieve interacties vanaf het beginpunt te volgen. Door oog te hebben voor de ontwikkeling van deze interactie wordt inzichtelijk welke subtiele handelingen succesvol zijn, zoals de verschillende strategieën die gericht zijn op het voorkomen van gezichtsverlies van reizigers, en welke beter vermeden kunnen worden. Juist door hier nader op in te gaan kunnen we deze 'kennis' en 'vaardigheden' expliciteren en aanwenden bij het voorkomen van agressie tegen personeel met een publieke functie.

Tot slot geven we aan dat het verkrijgen van inzicht in het perspectief van personeel met een publieke functie essentieel is om de ontwikkeling van agressieve interacties te kunnen begrijpen. Het zijn juist de betekenissen die dit personeel geeft aan agressieve interacties en aan hun werkcontext, die bepalend zijn voor het verloop van agressieve interacties. Om zicht te krijgen op het proces van betekenisgeving zijn 'open' interviews noodzakelijk. In het bijzonder stellen wij dat in vervolgonderzoek aandacht moet zijn voor de rol van masculiene normen en waarden, zoals eergevoel, autonomie, risico's nemen, territoriumdrift en lichamelijke weerbaarheid, bij de betekenisgeving van agressie in de tram.

\section{Literatuur}

Aa, S. van der, A. Pemberton, B. Vorm, J. Kesteren \& R. Letschert (2008), Evaluatie van de strafvorderingsrichtlijn kwalificerende slachtoffers. Tilburg: Intervict.

Abraham, M., S. Flight \& W. Roorda (2011), Agressie en geweld tegen werknemers met een publieke taak. Onderzoek voor Veilige Publieke Taak, 2007-2009-2011. Amsterdam: DSP.

Alpert, G.P., R.R. Dunham \& J.M. MacDonald (2004), Interactive police-citizen encounters that result in force. Police Quarterly, 7(4), 475-488.

Anderson, T., K. Daly \& L. Rapp (2009), Clubbing masculinities and crime: A qualitative study of Philadelphia nightclub scenes. Feminist Criminology, 4, 302.

Athens, L. (2005), Violent encounters: Violent engagements, skirmishes, and tiffs. Journal of Contemporary Ethnography, 34(6), 631-678.

Bakker, R. (2009), Agressie en geweld: Onderzoek naar agressie tegen overheidspersoneel. Den Haag: Ministerie van BZK.

Bakker, I., L. Drost \& W. Roeleveld (2010), Wat hebben geweldplegers gemeen? Een typologie van plegers van geweld tegen de publieke taak en van publiek geweld. Utrecht: Verwey Jonker Instituut.

Beke, B.M.W.A., W.J.M. de Haan \& G.J. Terlouw (1999), Geweld verteld: daders, slachtoffers en getuigen over geweld op straat. Den Haag: WODC.

Bergman, E., H. Valk \& M. de Vries (2013), Agressie tegen publieke dienstverleners. Antwerpen: Maklu.

Blokland, T.V. \& R. Soenen (2004), Veilig met de tram: een etnografisch perspectief op veiligheid in het openbaar vervoer. B\&M: Tijdschrift voor beleid, politiek en maatschappij, 31(3), 173-184.

Decorte, T. \& D. Zaitch (2010), Kwalitatieve methoden en technieken in de criminologie. Leuven: Acco. 
Goffman, E. (1959), The Presentation of Self in Everyday Life. New York: Anchor Books.

Goffman, E. (1971), Relations in Public Places. Microstudies of the Public Order. New York: Harper \& Row.

Hochschild, A.R. (1983), The Managed Heart: Commercialization of Human Feeling. Berkeley, CA: University of California Press.

Jacobs, M., M. Jans \& B. Roman (2009), Aard en omvang van ongewenst gedrag tegen werknemers met een publieke taak. Een vervolgonderzoek. Tilburg: IVA.

Kaldenbach, H. (2008), Respect! 99 tips voor het omgaan met jongeren in de straatcultuur. Amsterdam: Prometheus.

Leiden, I. van, N. Arts \& H. Ferwerda (2009), Rellen om te rellen. Een studie naar grootschalige openbare-ordeverstoringen en notoire ordeverstoorders. Politiekunde 25, Apeldoorn: Politie en Wetenschap.

Messerschmidt, J.W. (1993), Masculinities and Crime: Critique and Reconceptualization of Theory. Lanham, MD: Rowman \& Littlefield.

Messerschmidt, J.W. (2000), Nine Lives: Adolescent Masculinities, the Body, and Violence. Boulder, CO: Westview.

Messerschmidt, J.W. (2004), Flesh and Blood: Adolescent Gender Diversity and Violence. Oxford, UK: Rowan and Littlefield.

Middelhoven, L.K. \& F.M.H.M. Driessen (2001), Geweld tegen werknemers in de (semi-)openbare ruimte. Utrecht: Bureau Driessen, Sociaal Wetenschappelijk Onderzoek.

Montfort, P. van, R. Hogendoorn, C. Kolar \& E. Visser (2009), Belevingsonderzoekveiligheid, agressie en geweld. Nulmeting sector gemeenten. Internet Spiegel.

Raven, J. \& F.M.H.M. Driessen (2004), Agressie en geweld tegen ambtenaren van de gemeente Amsterdam. Utrecht: Bureau Driessen.

Roeleveld, W. \& I. Bakker (2010), Slachtoffers van geweld binnen de publieke taak. Utrecht: Verwey Jonker Instituut.

Sikkema, C.Y., M. Abraham \& S. Flight (2007), Ongewenst gedrag besproken. Ongewenst gedrag tegen werknemers met een publieke taak. Amsterdam: DSP-groep.

Spradley, J. (ed.) (1972), Culture and Cognition: Rules, Maps, and Plans. San Francisco: Freeman.

Stokkom, B. van (2010), Wat een hufter! Ergernis, lichtgeraaktheid en maatschappelijke verruwing. Amsterdam: Boom

Strauss, A. \& J. Corbin (1998), Basics of Qualitative Research: Techniques and Procedures for Developing Grounded Theory. Thousand Oaks, CA: Sage.

Timmer, J. (2005), Politiegeweld. Geweldgebruik van en tegen de politie in Nederland. Alphen aan den Rijn: Kluwer.

Verschuren, S., T. Fischer \& B. Zwirs (2011), Slachtofferschap onder treinconducteurs; De rol van sociale informatieverwerking, Tijdschrift voor Criminologie, 53(3), 194-213.

Vught, M. \& S. Bogearts (2007), Aard en omvang agressie en geweld tegen werknemers met een publieke taak. Quickscan. Tilburg: Intervict.

Vynckier, G., W. de Haan, O. Adang \& F. Goossens (2012), Geweld en politie. Cahier Politiestudies (nr. 23). Antwerpen: Maklu.

West, C. \& D.H. Zimmerman (1987), Doing gender. Gender \& society, 1(2), 125-151.

www.trouw.nl/tr/nl/4324/Nieuws/article/detail/1841113/2011/01/31/Offensief-tegengeweld-in-het-openbaar-vervoer.dhtml.

www.volkskrant.nl/vk/nl/2844/Archief/archief/article/detail/732538/2003/03/15/Wildestaking-trampersoneel-wegens-geweld.dhtml. 